\title{
Political communication science as a research area: history and contemporaneity
}

\author{
Marina A. Chekunova ${ }^{1, *}$ \\ ${ }^{1}$ PFUR, Department of mass communications, 115419, Moscow, Russia
}

\begin{abstract}
This article presents main markers of the research line named political communication science. The analysis of the foreign literature has allowed the author not only to establish the stages and the current status of the mentioned research field but to demonstrate the current level of knowledge of political communication. This article reveals the tight interrelation between genesis of political communication science and the theoretical understanding of state administration, efficiency and legitimacy of administrative authority decisions. The research area of the western political system was shown restricted up to the solution of particular issues, whereby the author considers the problem how to move the political ccommunication science to a new level by means of expansion of research interest in media sphere, political advertizing, PR and even awareness campaign.
\end{abstract}

The modern political science considers the term of political ccommunication in different aspects. However the trend to study and analyze the communication components of the power is becoming more significant. It is expected that within modern democratic states an interaction between government authorities and different members of a political process principally with civil society institution is provided by political communication instruments and feedback mechanism forming. In this regard there is growing number of communication inspections on different issues of state administration within western countries. There's been a set of significant changes of political communication sphere during the last years:

firstly, the continuous (as modern information technology advances) complication of communication component of political realities;

secondly, the growth of horizontal («dialogue») level of political communication in modern political process;

thirdly, the enhancement of dependency between the legitimacy of the decisions made and the intensity of the power-society interaction.

The scientific literature points a whole set of reasons anyhow affected the modern political communication systems transformation:

1) modernization, complicated the political communication objectives by virtue of increasing social differentiation and fragmentation of social organizations and interests;

2) individualization, decreasing the role of traditional social and political intuitions and turning the citizen into «consumers» of political services;

3) economization, meaning the growth of the economic factors influence over political agenda;
4) aestheticization, appearing in increasing role of style, image and culture practices;

5) rationalization, meaning the target and reasonable use of administrative resources during the political decisions development and making;

6) mediatization, meaning the growth of media value as the centers of social and political processes [1].

These new trends set new tasks both for society and political science. Every step forward requires not only clear understanding of scientific tools which are adequate to the reality of the today's world, but the consideration of the covered research way. Therefore the analysis of the political ccommunication science genesis as a research area requires considering different research spheres and fields (state administration, mass communication, political systems, media etc.).

The initial stage of political communication establishment connected with origination in the $18^{\text {th }}$ century of the communication theory foundations itself. Thus A. Smith describes the communication as the premise for division of labor, organizing the economic activity. Later the term «communication» appeared in political economic theories of money being the symbolic means of communication. In XIX century the ideas of communication science were naturally fit for the sociological belief of communication as a condition for community and society existence. Due to the technical progress within the $19^{\text {th }}$ and the $20^{\text {th }}$ centuries the communication theory rose to a new level. As a result, by the middle of the $20^{\text {th }}$ century the communication was interpreted principally as the universal process of information transformation. The ideas of Claude Shannon and Warren Weaver assert influence over development of the early communication models. The

Corresponding author: chekunova@gmail.com 
linear model of communication process offered by mathematicians immediately attracted politologists and experts in media. Nevertheless, the common logic of communication interaction explanation was based on cybernetic models [2, 3].

Several scholarly traditions can be distinguished in the second half of the $20^{\text {th }}$ century, which had significant influence over the communication theory development. Thus we should mention Charles Cooley's contribution to the theory of interpersonal communication and Robert Park's ideas of communication as a society basis among Chicago school and also Harold Lasswell, offered the first conceptual scheme of society mass communication [4]. As for Harvard school, its most prominent representatives were Talcott Parsons, Paul Lazarsfeld and Robert Merton [5].

The process of institutionalization of political communication problem field in western political science concurred with the period of discipline-related scientific conferences and construction of general political communication theory. This principally refers to Gabriel Almond's political system theory, which introduced a concept of «political communication». Considering the political life as an open system, the famous American politologist descried three system functions of political process - socialization, recruitment and communication [6]. The communication nature of power is introduced also in David Easton's studies, who determined the power as a type of political communication [7]. The process of new research area institutionalization ended with creation in 1973 within the framework of International communication association of an independent subdivision of political communication and the establishment of specialized magazine «Political Communication Review», under the editorship of political psychologist Doris Graber from Chicago University, next year [8].

Ever since the political communication has turned into an independent research area and inspired by different factors (technical progress, scientific paradigm change, complication of political worldview) has achieved a new quality. The political communication was earlier interpreted as a process of creation, distribution and perception of political information, based on creation of social political senses and consensus building in respect of one or another political action. The expression of political communication as an information channel and one-way communication is of a linear logic type.

The modern understanding of political communication doesn't confine to simple data exchange. A message is constructed through the specific interaction between different actors, i.e. the modern communicative management tries to control the process of sense creation [9]. The management of communication in unstable media becomes the key objective of state administration, instead of information control within rather stable conditions. According to an idea of «viewer society» by T. Mathiesen, such society is structured around wide communication system, allowing the majority to control the minority. In this case the efficiency of state administration becomes depending on all types of communication activity [10].

All mentioned above confirms the significant changes of political communication understanding within the system of state administration. While the mechanisms of informing and persuasion in political area were mostly studied earlier, nowadays the emphasis is placed upon administrative characteristics of political and communication process. Moreover, the modern concepts of power, for all of their differences, are concentrated on communicative aspects of power, treated as some communicative connecting mechanism. In the same way the political component of the modern society is studied as a community interacting for joint problem resolution, whereas the political communication is understood as interaction process on administrative authority decisions.

Therefore it is important to evaluate the degree of the influence on theoretical grounds development of political communication science, state administration theory and connected problematic of power efficiency and legitimacy. Usually this sphere was considered as hierarchy system of power relations on political course establishment and realization. But the contradiction between hierarchy from of state administration and strengthening of dynamism, variety and complexity of the modern society has gradually moved the research interest towards studying the interaction of power and society institutions [11]. "The foundation» of nonhierarchy administration types based on interaction between state and non-state actors, eliminates the differences of interaction between state and non-state sectors. Finally the state administration is considered as multilateral process, including power, business and civil society institutions based on the partnership between these actors.

Such transformation of beliefs on state administration has its own logic. Administrative paradigm has made a long journey since $1960^{\text {th }}$, starting its development within the frames of planning theory. As late as in $1970^{\text {th }}$ the problems of political development and realization of different political courses inter alia, became the object of the analysis. Earlier the subject of political administration and management was in the main focus, but now the research accents were moved towards objects which the political action is aimed on. The first step was attention for electoral consent of different demographic groups with the carried political course.

The further development of state administration concepts were connected with managerialism expansion, transferring the corporate management of businessstructures aimed on a profit achievement and service rendering to community, to the area of politics and state administrations. By these means the function of the state reduces itself to service obligations to different demographic groups. However within the frames of this theoretical turn the classical principles of bureaucracy functioning (rationality, formalized procedures, clarity, precision, accountability to a society, stability towards corruption) were not touched. It was limited to a recovery of bureaucratic hierarchy incidental to state administration. 
The analysis of theoretical conceptions of state administration, which were developed in the political science during the last decades, demonstrates the transfer from a principle of hierarchy dominance to an idea of partnership, interest alignment and mutually beneficial cooperation. Furthermore, the system of political communication as the complex of state and social interactions on legitimacy of social and political issues resolving becomes the crucial one within the state administration.

In the last twenty years besides the old approach to the state administration as unidirectional process of political management there were models developing with the focus on multi-directional processes and new forms of power-society interactions.

Among the peculiarities of a modern understanding of the state administration and accordingly the factors affecting the intensity and quality of interactions there are: stray from guidelines of hierarchy management; the acknowledgment of blurring of distinction between state and society; the acknowledgment and incorporation of problem and political nets through the state administration process; the replacement of traditional hierarchy control to so called «distant» management; the enhancement of institutional possibilities to involve civil society into the state administration process. The possibility of public and administrative authorities and certain politicians to communicate efficiently with different members of political process takes on enormous importance in procurement of legitimacy of taken political decisions in the modern society. Such approach for the state administration represents a communication system, and the communication itself is a form of interactive politics [12].

Such transformations are followed by darkening the essentials discussions on changing role of a state. The truth is that the modern conceptions of the state administration area aimed not only on depriving the power's monopoly to make political decisions but also on decreasing of state presence in different social living environment. In several cases (the liberal idea of minimal participation of a state and net theory of a state «management without a state») it is even not concealed. In other theories the idea of «night watchman» is disguised to different extents. This way the theory of corporate management reduces the relations between a state and society to a formula «managers shareholders», and the conception of «good management» offered by the World Bank includes mechanisms and institutes, by means of which the citizens and social group express their interests. Speculating the idea of society complication the theory of social and cybernetic management declares the traditional political institutions obsolete. According to the conception of interactive management neither a state nor a society themselves can create the practical mechanism to resolve vital problems. However a separation of the functions between state and non-state institutions is the result of agreement between them [13].

In the light of the foregoing the dialog with the civil society and other non-state actors turns into major criterion of the state administration efficiency. With such approach the performance and efficiency of management acquire the political and communicational grounds.

One more important feature is that the request for the maximal clarity of the state authority actions begins to associate with wide participation of different interest groups during the process of political decisions making. As a result of communication interaction between state and non-state actors the quality of the state management improves as well as the level of power legitimacy of all and any of political decisions increases. The modern political science the legitimacy is considered as operational characteristic of a state management performance. The latter as it was stated above is becoming more and more connected with the communication component of the power relations.

Within all the variety of viewpoints for the interpretation of the term «legitimacy» (table № 1) [1427], nowadays the power legitimacy is more often specified by the system of communication interactions between political elite and society.

Table № 1. The main conceptions of legitimacy (Blank line means there is no original interpretation of the category «legitimacy of power» or its sources)

\begin{tabular}{|c|c|c|c|}
\hline $\begin{array}{l}\text { S. } \\
\text { No. }\end{array}$ & $\begin{array}{l}\text { The author of } \\
\text { a concept }\end{array}$ & $\begin{array}{c}\text { Power legitimacy } \\
\text { definition. }\end{array}$ & $\begin{array}{l}\text { Power } \\
\text { legitimacy } \\
\text { sources }\end{array}$ \\
\hline 1 & J. Habermas & $\begin{array}{l}\text { «Possibility of } \\
\text { political order to be } \\
\text { acknowledged». }\end{array}$ & \\
\hline \multirow[t]{6}{*}{2} & P. Bourdieu & $\begin{array}{l}\text { «A kind of a credit, } \\
\text { which one entrusts } \\
\text { another with, } \\
\text { enclosing his trust». }\end{array}$ & $\begin{array}{l}\text { The belief that } \\
\text { power exists. }\end{array}$ \\
\hline & C.R. Mills & $\begin{array}{l}\text { The possibility of the } \\
\text { social elite to ensure } \\
\text { its institutional } \\
\text { supremacy by means } \\
\text { of efficient «beliefs } \\
\text { moral symbols, } \\
\text { sacred emblems and } \\
\text { legal formula». }\end{array}$ & $\begin{array}{l}\text { The belief in } \\
\text { moral symbols } \\
\text { and legal } \\
\text { formula. }\end{array}$ \\
\hline & S. Lipset & $\begin{array}{l}\text { The power is } \\
\text { legitimate if it is } \\
\text { overall justified by } \\
\text { the subjects. }\end{array}$ & $\begin{array}{l}\text { The belief that } \\
\text { existed } \\
\text { political } \\
\text { institutes are } \\
\text { the best for } \\
\text { this society. }\end{array}$ \\
\hline & M. Duverger & $\begin{array}{l}\text { Every regime the } \\
\text { nations agree with is } \\
\text { legitimate. }\end{array}$ & \\
\hline & J. Linz & $\begin{array}{l}\text { «The belief that } \\
\text { despite all mistakes } \\
\text { and disadvantages } \\
\text { the existing political } \\
\text { institutions are the } \\
\text { best». }\end{array}$ & \\
\hline & $\begin{array}{l}\text { K. } \\
\text { Zavershinskiy }\end{array}$ & $\begin{array}{l}\text { The process of } \\
\text { «justification», } \\
\text { «reasonability», } \\
\text { «solubility» and } \\
\text { «conformance» of } \\
\text { institutional order } \\
\text { typical of any } \\
\text { politics. }\end{array}$ & \\
\hline
\end{tabular}




\begin{tabular}{|c|c|}
\hline C. Merriam & $\begin{array}{l}\text { External } \\
\text { safety, internal } \\
\text { order, overall } \\
\text { wealth, } \\
\text { freedom and } \\
\text { justice. }\end{array}$ \\
\hline B. Gilley & $\begin{array}{l}\text { The level of } \\
\text { economic } \\
\text { growth and } \\
\text { personal } \\
\text { financial } \\
\text { satisfaction. }\end{array}$ \\
\hline B. Radcliffe & $\begin{array}{l}\text { The feeling of } \\
\text { life } \\
\text { satisfaction. }\end{array}$ \\
\hline N. Munro & $\begin{array}{l}\text { The level of } \\
\text { personal } \\
\text { material } \\
\text { satisfaction. }\end{array}$ \\
\hline M. Waterford & $\begin{array}{l}\text { Political } \\
\text { interest and } \\
\text { political } \\
\text { efficiency of } \\
\text { the power. }\end{array}$ \\
\hline J. Coleman & $\begin{array}{l}\text { Level of social } \\
\text { confidence } \\
\text { and social } \\
\text { capital. }\end{array}$ \\
\hline J. Spider & $\begin{array}{l}\text { Limits of civil } \\
\text { involvement, } \\
\text { cooperation } \\
\text { with the } \\
\text { community. }\end{array}$ \\
\hline L. Diamond & $\begin{array}{l}\text { Performance } \\
\text { of political } \\
\text { system. }\end{array}$ \\
\hline
\end{tabular}

We see that today besides the listed normative, economic, social and international legitimacy determinants the significant role is devoted to new factors of power legitimacy - communication possibilities, resources and ability of the public and administrative authorities and certain politicians to communicate efficiently with different members of political process. Thus the sociologists pay attention to social confidence and correspondence between political system and citizens' expectations. The legitimacy within such approach is «horizontal» integration level of political institutions, based on acknowledgement of the common sense of political process by the members of communication. But hereby the modern science considers the political communication rather as an addition than a replacement of electoral procedure.

At the same time the research area of political communication science, more correlating with the sphere of state politics and administration research (mostly in the field of performance, efficiency and legitimacy of taken decisions) is reducing to a particular issue level. Thus the modern practices are looking to the resolution of at least three issues of the communication: the main working issues of a certain power body, procedural components of decision making and also the performance and accountability of the political and administrative decisions taken. Of course there are no doubts in importance of the studied problematic.
However the perspectives of moving the political ccommunication science to a new level are seemed to be resolved by means of expansion of modern researches' interest in media sphere, political advertizing, PR and even awareness campaign.

\section{References}

1. J.G. Blumler, and D. Kavanagh, Political Communication, 16, 209-230, (1999).

2. M.N. Grachev, Political communication: theoretical conceptions, models, vectors of development (Moscow, 2004);

3. A.I. Solovyov, Polis, 3 (2002).

4. H.D. Lasswell, The structure and function of communication in society (Harper and Brothers, New York, 1948).

5. P. Lazarsfeld, and R. Merton, Mass Communication, popular taste and organized social action (Harper and Brothers, New York, 1948).

6. G. Almond, Political science: a history of the discipline (Moscow, 1999).

7. D. Easton, A theoretical approach to authority (Stanford University, Stanford, 1953).

8. C.H. de Vreese, Ten Observations about the Past, Present and Future of Political Communication. (University Press, Amsterdam, 2006).

9. M. Crozier, Political Communication, 24, 1-18 (2007).

10. T. Mathiesen, Theoretical Criminology, 1, 215-234 (1997).

11. M. Crozier, Political Communication, 24, 1-18 (2007).

12. H.P. Bang, Governance as social and political communication (University Press, Manchester, 2003).

13. J. Kooiman, Public Management Review, 1, 67-92 (1999).

14. P. Bourdieu, Sociology of politics (Socio-Logos, Moscow, 1993).

15. M. Dogan, Socis, 6, 147-156 (1994).

16. K.F. Zavershinskiy, Polis, 2, 113-131 (2001).

17. C. Mills, The Sociological Imagination (Moscow, 1998).

18. J-L. Shabot, Polis, 5 (1993).

19. J. Coleman, Foundations of Social Theory (Harvard University Press, Cambridge, 1990).

20. L. Diamond, Developing Democracy: Toward Consolidation (Johns Hopkins University Press, Baltimore, 1999).

21. B. Gilley, International Political Science Review, 27, 47-71 (2006).

22. F. Fukuyama, Trust (Basic Books, New York, 1995).

23. Ch. Merriam, Systematic Politics (University of Chicago Press, Chicago, 1945).

24. N. Munro, J. Commun. Stud. Transit. Polit., 18, 103126 (2002).

25. B. Radcliff, APSR, 95, 939-953 (2001).

26. J. Snyder, From Voting to Violence: Democratization and Nationalist Conflict (W.W. Norton, New York, 2002).

27. M.S. Weatherford, Political Behavior, 9, 5-28 (1987). 